\title{
MUUTOS, HAASTE, VALINTA
}

S anat muutos, haaste ja valinta ovat tunnuksena USA:n yliopistojen täydennyskoulutuskeskusten johtajien järjestön vuosikokouksessa tänä keväänä. Ne kuvaavat eri puolilla maailmaa aikuiskasvatukselle tunnusomaisia piirteitä.

Suuret muutokset sekä koulutusrakenteissa ja ennen kaikkia sisällöissä ja toimintatavoissa ovat välttämättömiä yhteiskunnan tarpeiden vaihtuessa. Työelämän vaatimukset muuttuvat. Taloudelliset tilanteet vaihtuvat. Kansainvälinen yhteistyö tulee osaksi jokapäiväistä elämäämme. Ja uuden tiedon määrä lisääntyy. Tämä kaikki aiheuttaa sen, että aikuiskouluttajat emme voi pitäytyä pelkästään hyviksi havaituissa, jo turvallisiksi muodostuneissa perinteissä.

S uuret muutospaineet voidaan kokea haasteina. Monilla meistä, jotka olemme toimineet jo vuosia, jopa vuosikymmeniä vastaavissa tehtävissä, uudet haasteet saattavat auttaa uusiutumaan ja etsimään erilaisia toimintatapoja. Parhaimmillaan tämä antaa uutta sisältöä elämäämme ja auttaa pitämään myös omaa hengenpaloamme yllä.

Aikuiskoulutuksen parissa työskentelee niin ammattitaitoinen henkilöstö, että emme saa tyytyä vain reagoimaan muutoksiin. Meidän on myös vaikutettava aktiivisesti tulevaisuuden muotoutumiseen. Aikuisten kouluttamisen ohella meidän tulisi osallistua entistä enemmän keskusteluun siitä, mihin haluamme ohjata yhteiskunnan kehitystä. Tulevaisuuden visioiden luominen edellyttää arvokeskustelua.

Aikuiskoulutusorganisaatioissa toimivien tulisi olla omassa työssään malleina hallitusta, jatkuvasta muutoksesta. Käytännössä kuitenkin muutokset aiheuttavat kitkaa. Uudistuksiin liit- tyvät erilaiset pelot ja ahdistus. Osaamattomuuden pelko ja epäilys oman työpaikan jatkuvuudesta johtavat meidät usein puolustusasemiin, jotka ehkäisevät uusien vaihtoehtojen etsinnän.

Muutospaineista selviäminen ja olemassaolon turvaaminen edellyttävät vahvaa johtajuutta aikuiskoulutusorganisaatioissa. Johtajalla tulisi olla näkemyksïa siitä, mihin suuntaan toimintaa ohjataan ja miten rahoituspohja turvataan. Hänen on mietittävä tavoitteita yhdessä henkilökuntansa kanssa ja saatava kaikki sitoutumaan niihin.

Ratkaisevaa koulutusorganisaatioiden jatkuvan kehittämisen kannalta on oman henkilökunnan ammattitaidon kehittyminen. Johtajan olisikin pidettävä huolta myös henkilökuntansa jatkuvasta kehittämisestä.

Yksi tärkeimmistä johtajan tehtävistä on huolehtia henkilökunnan työkykyisyydestä. Johtajan olisi tuotava turvallisuutta työyhteisöön muuttuvissa olosuhteissa. Hänen tulisi kyetä miettimään työtilanteita uudelleen jonkun työntekijän stressaantuessa ja väsyessä liikaa.

$\mathbf{S}$ uurten yhteiskunnallisten uudistusten ja erilaisten taloudellisten tilanteiden muutoksen takia meidän on jatkuvasti tehtävä valintoja. Mitä koulutusta tarjoamme, mistä kohderyhmistä pidämme huolta? Tutkimusta tulisi kohdistaa entistä enemmän aikuiskoulutusorganisaatioiden toimintaan, niiden sisältöihin, koulutuksen toteuttamistapoihin, kohderyhmiin ja talouden hoitoon.

$\mathbf{P}$ ohtiessamme aikuiskoulutuksen tulevaisuutta meidän on hyvä tuntea joitakin päävirtauksia ja keskustelun kohteita muualla Eu- 
roopassa. Näin voimme arvioida nykyisten järjestelmiemme vahvuuksia ja kehittämistarpeita. Siksi tämän lehden teemaksi on valittu kansainvälinen ja eurooppalainen näkökulma aikuiskasvatukseen.

Kansainvälisten virtausten tarkastelun pitäisi rohkaista suomalaisia ymmärtämään, että voisimme olla itse paljon enemmän antavana puolena kansainvälisessä keskustelussa. Esimerkiksi vapaan sivistystyön organisointi, tehokkuus, osanottajamäärät ja kattavuus kelpaisivat hyvin malliksi useimpiin Euroopan maihin. Myös yliopistojen täydennyskoulutusorganisaatio on herättänyt myönteistä huomiota maailmalla.

Koulutusorganisaatioiden välisen kilpailun lisääntyessä ja taloudellisen pohjan heikentyessä eri maissa on yksi keskeinen keskustelun kohde ollut se, miten aikuiskoulutuksen tulisi kohdistua. Pitäisikö koulutusorganisaatioiden olla tietosampoja ja kehittämiskeskuksia, jotka turvaavat kansainvälisen kilpailukykymme? Vai olisiko parempi keskittyä pitämään huolta henkilöistä, jotka ovat syrjäytyneet kilpailuyhteiskunnasta, lukutaidottomista, työttömistä, vajaatyökykyisistä jne.? Entä onko perinteisellä kansansivistystyöllä enää merkitystä?

outuessamme hankkimaan uusia rahoituslähteitä toiminnallemme painotamme helposti välitöntä hyötyä tuottavaa, ammatillisesti pätevöittävää tai muodollisen kelpoisuuden antavaa koulutusta. Kuitenkin kansainvälistyminen, kuten monet muutkin tekijät, lisäävät laaja-alaisen ja yleissivistävän koulutuksen merkitystä. Oman ja muiden kulttuurien tuntemus ja kommunikointitaidot ovat esimerkkejä jatkuvasti merkityksensä säilyttävistä koulutustarpeista.

Olemme siis suurten valintojen edessä. Kaikki lienemme yksimielisiä siitä, että aikuiskasvatuksen merkitys kasvaa edelleenkin. Mutta mitkä organisaatiot huolehtivat siitä ja minkälaisen ammattitaidon omaavat työntekijät työskentelevät niissä, riippuu meistä itsestämme. Organisaatiomme oma oppiminen on ratkaisevaa. Monivuotisten suunnitelmien tekeminen lienee mahdotonta muuttuvissa olosuhteissa, joissa joudumme luomaan jatkuvasti uusia ratkaisuja. Mutta jonkinlaista visionäärisyyttä meiltä edellytetään.

$\mathbf{K}$ ovassa kilpailutilanteessa maassamme toimivat yli 1000 aikuiskoulutusta antavaa organisaatiota voisivat olla mallina myös keskinäisen yhteistyön kehittämisessä. Myös kansainvälistyminen korostaa yhteistyön merkitystä.

Koulutusorganisaatiot voisivat laajentaa tehtäväkenttäänsä perinteisten koulutustehtävien ulkopuolelle. Monilla niistä voisi olla myös monipuolisia kulttuurisia tehtäviä. 